\title{
HEIDEGGEROVA KRITIKA BOLJŠEVIZMA I LIBERALIZMA
}

\section{Goran Gretić}

DOI: $10.20901 / a n .13 .04$

Sveučilište u Zagrebu

E-mail: ggretic45@gmail.com

Sažetak U članku se razmatra Heideggerova predanost ideji nacionalsocijalizma, te kroz kontekstualno čitanje Crnih bilježnica, njegova kritika boljševičkog komunizma i anglo-američkog liberalizma. Kroz raspravu o intelektualnom i povijesnom kontekstu u kojem su Crne bilježnice pisane, autor pruža uvid u Heideggerov osebujni antisemitizam koji je povezan s njegovim filozofskim projektom o povijesnosti bitka. Takav pristup je, autor pokazuje, u srži Heideggerove kritike sovjetskog komunizma. Završni dio rada posvećen je usporedbi Dostojevskog i njegova viđenja uloge ruskoga naroda s Heideggerovim promišljanjima o toj temi.

Ključne riječi Heidegger, Crne bilježnice, nacionalsocijalizam, komunizam, boljševizam, liberalizam

U filozofiranju nikada ne misliti na "druge", i isto tako malo na "ja", jedino o i na izvorište bitka - to se podjednako odnosi na stvari i put.

\section{Martin Heidegger, Schwarze Hefte}

Usprkos svih otpora, izokretanja i ponovnih udaraca ne skretati i ne popuštati.

Ali čemu pokušavati u nekom napuštenom kutu?

Martin Heidegger, Schwarze Hefte

Heidegger svoja promišljanja i komentare u posljednjem, posthumno objavljenom djelu pod naslovom Crne bilježnice, izričito označava kao osvješćenja (Besinnungen), a ne kao aforizme i životne mudrost. Taj pojam osvješćenja (koji u njemačkom jeziku ima izrazito teologijske konotacije) Heidegger određuje na sljedeći, za njega tipični, metaforičkokriptički, način: "Osvješćenje ne misli bilo kakvo promišljanje, promišljenost ili čak sumnjičavost, već skok-unaprijed $\mathrm{u}$ istinu bitka Ta je bit osvješćenja jedin- stveno ista sa jedinstvenosti njenog trenutka” (Heidegger, 2014d: 37). I valja odmah na početku naglasiti da Crne bilježnice, po općoj ocjeni, svakako predstavljaju veliku cenzuru u vrednovanju Heideggerovog cjelokupnog djela. ${ }^{1}$

1 O tome u međuvremenu postoji dosta literature, kao prvo to su dva zboriika o Crnim bilježnicama: Heinz i Kellerer, 2016; Gander i Striet, 2016; vidi i: Trawny, 2016; Di Cesare, 2015. 
Tekst Crnih bilježnica, za sada, čine četiri knjige sa skoro 1800 stranica, i u njima je riječ o svojevrsnom misaonom dnevniku koji je pisan od 1931. do 1948. Te je "Bilježnice" Heidegger pedantno vlastoručno korigirao i priredio za objavljivanje, s time da su "Bilježnice" određene da čine završne sveske njegovih cjelokupnih djela. Prema tome nedvojbeno je kako je sam Heidegger namijenio sasvim posebnu ulogu tim Crnim bilježnicama, te se opravdano može govoriti o svojevrsnom filozofijskom testamentu, a čije je objavljivanje, za pretpostaviti je promišljeno, određeno za daleku budućnost. Međutim, sam se sadržaj Crnih bilježnica pokazuje kao nešto novo i svakako iznenađujuće s obzirom na do sada poznata Heideggerova filozofijska djela. Naime, u Bilježnicama je dokumentirano i takoreći teorijski obrazloženo, i to u pojmovlju Heideggerovog djela Bitak $i$ vrijeme, tj. fundamentalne ontologije, njegovo vrlo živo i intenzivno promišljanje i analiziranje historijskih zbivanja, kao i strastveni interes na ideološkim, političkim i svjetonazorskim prijeporima toga razdoblja, čak do razine onog dnevno političkoga.

Stoga za početak može ustanoviti kako se Herideggerova osvješćenja iz Crnih bilježnica u bitnom svode na sljedeće problemske sklopove: povijesna uloga Njemačke; bit nacionalizma kao drugog početka povijesti bitka; odnos Nijemci - židovstvo - Zapad; svjetskopovijesna jednakost liberalizma-amerikanizma i komunizma-boljševizma. Uz to Heidegger se posebno bavi odnosom Nijemaca i Rusa, problemom Rusije kao takve, kao i opasnosti boljševizma, a kojega on izjednačava sa svjetskim židovstvom. U IV. svesku koji sadrži bilješke od 1942. do 1948. izlazi na vidjelo njegova vrlo iritantna i cinična, potpuna i decidirana nespremnost uvidjeti i priznati bilo kakvu vrstu njemačke krivnje i moralno-političke odgovornosti za katastrofu Drugog svjetskog rata i holokausta. I, dakako, on se neprestano i na različite načine obračunava sa najrazličitijim krivim, nedostatnim i sasvim nepromišljenim tumačenjima djela Bitak $i$ vrijeme, tako da se doista zadobiva dojam da je to za njega bilo jedino i mjerodavno djelo.

Istovremeno on stilizira svoj vlastiti politički angažman u nacionalsocijalističkom režimu od 1933. kao profetsko upozoravanje na pogrešni razvoj toga novog početka svjetske povijesti, a u liku nacionalsocijalističkog pokreta. Po Heideggeru se tada zbivalo tako nešto kao navlastiti "novi početak", a koga je promatrano iz povijesti bitka, valjalo odobravati "iz misaonih razloga”. Osim toga Heidegger nas opširno izvještava kako je on zapravo još od 1933. pa sve do kraja pisanja tih Bilježnica, bio stalno ometan i denunciran od raznoraznih neukih, tj. misaono nesposobnih pristaša i ulizica režima. $^{2}$

2 Zasigurno je suvišno naglašavati kako je Heidegger živio i radio u sudbonosna, opasna i teška vremena. Od početka njegovih raznorodnih pokušaja sudjelovanja i oblikovanja onoga što je on vidio kao "veličinu i istinu toga pokreta”, tj. novog početka povijesti zapada putem nacional-socijalističkog pokreta, Heidegger je nedvojbeno bio vođen svojim navlastitim poimanjem povijesnosti, zadobivenim još u djelu "Bitak i vrijeme", (a to je, kao što je poznato, i sam izričito potvrdio u razgovoru sa Karlom Löwithom (Löwith, 1986). Prema tome, koliko god se danas mogu sa puno dobrih razloga i sa raznorodnim objašnjenjima, mnoga njegova stajališta najradikalnije odbacivati, on zasigurno nije bio nikakav vulgarni karijerist i oportunist. Stoga i nije nimalo iznenađujuće da je bio isto tako napadan od kojekakvih mizernih propagatora režima i intelektualnih i moralnih ništica, kao što je bio filozof Ernst Krieck, tadašnji rektor sveučilišta u Frankfurtu. U Crnim bilježnicama, navodi Hei- 
Gledajući cjelinu sadržaja tih Bilježnica mogla bi se sažeto istaknuti tri bitna problemska sklopa (neovisno o neprestanim pokušajima ispravljanja krivih interpretacija djela Bitak $i$ vrijeme) u Heideggerovim osvješćenjima.

1. Heidegger sam sebe deklarira, u različitim formulacijama, kao onog koji odobrava nacionalsocijalizam, dakako, ne u svakodnevnom vulgarnom smislu. Kod Heideggera je riječ, kako sam kaže, usprkos svih gorkih razočarenja kojima je bio izvrgnut, o nečem sasvim drugom, naime, nužnom "bitnom odobravanju” nacionalsocijalizma iz "misaonih razloga". Međutim, to od strane vladajućeg režima nije bilo niti respektirano ni honorirano, krivnju za to snose različite "prazne preuzetnosti "intelektualaca”".

2. Heidegger zastupa osebujni antisemitizam koji je utemeljen u povijesnosti bitka, tj. svjetskom se židovstvu pripisuje navlastita razarajuća uloga u zapadnjačkoj povijesti.

3. Moderne revolucije, prosvjetiteljstvo i liberalizam, amerikanizam i boljševizam-komunizam, odnosno: "Moderni sistemi totalne diktature imaju podrijetlo u židovsko-kršćanskom monoteizmu” (Heidegger, 2014a: 438).

Ta tri načelna problemska sklopa Heidegger još i povijesno konkretizira, obrazlažući kako se tada, naime, kon-

degger, kako ga često pitaju zašto "ne odgovara na blaćenje od gospodina Kricka”, te tim povodom Heidegger kaže sljedeće: “Odgovor: oni koji poradi svoje plitkosti i taštine, s kojom po svemu prekopavaju što je bilo oblikovano i mišljeno - takvi koji zaslužuju samo prezir, nikada ne mogu biti protivnici. $\mathrm{U}$ borbu idem samo sa protivnikom, ne sa hvalisavcima osrednjosti" (Heidegger, 2014b: 179). I u toj je stvari Heidegger doista bio $u$ pravu, na takve se pojave, na te quantite negligeable, zbilja ne treba osvrtati. cem 30-ih godina, povijesni tubitak čovjeka utemeljivao na tri elementa. A to su bili:

1. pojedinci, oni koji se danas bore;

2. žene, a koje putem izvorne ljubavi čuvaju nerazorive prostore ljubavi;

3. pjesnici i mislioci, a koji u prikrivenosti pjesnički priređuju ono buduće.

Zatim Heidegger objašnjava tegobno, ali i epohalno značenje uloge ta tri nositelja tadašnje povijesne egzistencije, a kako se otkrivaju u obzoru povijesti bitka. Oni, kako naglašava Heidegger, moraju voditi više nego "opasni život" i to usred trivijalno-vulgarne svakodnevnice. Međutim, u svemu tome bitno je da se njihovo djelovanje odvija u prikrivenosti, dok je istovremeno takva vrsta djelovanja bilo nešto "jedinstveno, jedinstveno kao početak naše zapadnjačke povijesti” (Heidegger, 2014c: 134). Ovo bi se tri određenja mogla i čitati kao osebujni primjeri sentimentalne poezije povijesti bitka.

Heidegger se u Crnim bilježnicama bavi izrazito opširno s problemom Rusije, onog ruskog, odnosno s boljševizmom, koji izjednačava sa svjetskim židovstvom. I tu valja odmah naglasiti da su takve tvrdnje bila daleko od bilo kakve originalnosti, odnosno, to je bila standardna ideološka teza nacionalsocijalističkog pokreta, a osobito propagandistički razrađivana u Hitlerovom djelu Mein Kampf. Kao što smo već naveli Heidegger promatra moderne revolucije, prosvjetiteljstvo, liberalizam, amerikanizam i komunizam-boljševizam kao "sisteme moderne totalitarne diktature" i svi ti fenomeni proizlaze "židovskokršćanskog monoteizma”. (Heidegger, 2014a: 438). Tu prijepornu, a zapravo apsurdnu tezu o navlastitom bitnom jedinstvu liberalizma-amerikanizma i komunizma-boljševizma razrađuje Hei- 
degger $u$ više navrata, na primjer na sljedeći način: "Zašto pripadaju najuže zajedno englesko-američki "svijet" i "boljševizam", usprkos prividne suprotstavljenosti kapitalizma i anti-kapitalizma? Jer su oboje u biti isto - bezuvjetno razvijanje subjektivnosti u čistu racionalnost. Tamo odgovara tome u protuzamahu ono "sentimentalno", ovdje (u boljševizmu) tupo azijatsko" (Heidegger, 2014c: 235).

Dakako, odmah se nameće pitanje po čemu su to kapitalizam i anti-kapitalizam suprotstavljenosti, prije bi izgledalo kako bi valja reći da su tu radi o oprekama. Međutim, da su oboje isto u smislu krajnje subjektivnosti i racionalnosti, samo je problematična i racionalno neobrazložena tvrdnja iz mišljenja povijesti bitka, o znanstveno-tehničko-tehnologijskoj konstituciji zapadnjačke metafizike, a označavanje angloameričkog kapitalizma kao neke "sentimentalnosti" zvuči više komično, nego ironično, dok je karakteriziranje azijatskog kao nečega tupoga, samo malograđanska vulgarnost. Međutim, u Crnim bilježnicama Heidegger se posebno bavi problemom onog ruskog i za to po njemu postoje dobri razlozi, naime, on kaže sljedeće: "Rusi stoljećima znaju puno toga i vrlo jasno o Nijemcima, o njihovoj metafizici i pjesništvu. Ali Nijemci ne slute ništa o Rusiji. Prije svakog praktičko-političkog pitanja, koje si mi moramo postaviti o Rusiji, stoji jedino pitanje, tko su zapravo Rusi. Kao što je komunizam (uzet kao bezuvjetni marksizam) tako je i moderna tehnika skroz na skroz europski-zapadna. Oboje su samo instrumenti onog ruskog, a ne ono samo. Ukoliko tehnika i komunizam navaljuju na zapad sa istoka, napada uistinu zapad protiv zapada u užasnom samouništenju svojih vlastitih snaga i tendencija...U onome ruskom nalazi svršenost metafizike primjereno mjesto svojega ponovnog rođenja" (ibid.: 276).

U suprotstavljenosti spram ta dva destruktivna lika svjetsko-povijesne konstelacije moderne, pokušava Heidegger ustanoviti i odrediti povijesnu ulogu Nijemaca na sljedeći način:

"Bit Nijemaca, njihovo povijesno određenje, izmiče se historijskom izračunavanju putem naroda i poznavanja povijesti; ona proizlazi jedino iz trenutka koji odlučuje o onome, a koje dapače leži u temelju "svjetsko-povijesnih" zbivanja, i čovjeka zapada gura ili u tu-bitak ili ga izručuje planetarnim tvorevinama (Machenschaften)” (ibid.: 55).

Ovdje svakako još valja navesti da između ovakvih samovoljnih svjetskopovijesnih spekulacija o ulozi pojedinih naroda, nailazimo u Crnim bilježnicama, nažalost, i na veliki broj vulgarnih invektiva spram tzv. amerikanizma i posebno protiv Engleske. Doduše, valja napomenuti da je određeni antianglosaksonski i antiromanski afekt bio dosta rasprostranjen u Njemačkoj još od 19. stoljeća. Na primjer, to je izričito vidljivo u radovima M. Schelera, od Heideggera visoko cijenjenog suvremenika, ali ako se smije tako reći, Schelerovi su napadi i sarkazmi bili puno duhovitiji i elegantniji ${ }^{3}$, i bez Heideggerovih često grotesknih preuzetnosti iz obzora povijesti bitka, na primjer kada objašnjava neprevođenje svojih djela na engleski, sa osrednjošću i metafizičkom nedostatnošću engleskog duha. Dakako, mnoštvo slično trivijalnih invektiva ima i spram Sovjetskog Saveza. (U tome je kontekstu i opravdano postaviti pitanje o sasvim osebujnoj

3 O povijesno-idejnim korijenima kritike zapada-liberalizma-romanizma kao nečega stranoga njemačkom biću, vidi: Gretić, 2012: 65-113. 
odgovornosti filozofije za tu, naizgled neshvatljivu, brutalnu provalu mržnje i nasilja nakon 1933. Pokazuje se kako je pri tome odlučno pitanje pod kojim i kakvim su se to socijalnim i kulturološkim uvjetima i okolnostima mogla razviti takva destruktivna, nihilistička stajališta, uvjerenja, raspoloženja? Odnosno, kojim je putovima postupno došlo do eksplozivnog širenja spremnosti ka besprimjerno bezumnoj destrukciji cjeline europske tradicije civilnog miroljubivog suživota pojedinaca i naroda, i sve to podržavano od strane ogromne većine stanovništva jednog velikog kulturnog naroda?)

Kao što smo naveli Heidegger se u više navrata upušta u spekulativna povijesno-filozofijska, iz povijesti bitka, promišljanja biti komunizma, boljševizma i engleske, tj. zapadno-liberalno-demokratske države. Tako on kaže sljedeće: "Ako je "komunizam" posljednje metafizičko ustrojstvo naroda u posljednjem odsjeku svršenosti novovjekovlja, tada to počiva na tome da je on morao uspostaviti svoju bit kao moć, iako još prikriveno, već na početku novovjekovlja. Politički se to događa kao novovjekovna povijest engleske države. Ona je... isto što i država Sovjetskih republika, samo sa tom razlikom, da tamo jedna ogromna predodžba privida moralnosti i odgoja naroda, ublažava sav razvoj nasilja i čini ga samorazumljivim. Dok ovdje [u engleskoj državi] novovjekovna "svijest" bezobzirnije, iako ne bez poziva ka usrećivanju naroda, razotkriva samu sebe kao vlastitu bit-kao-moć. Najopasnija je građansko-kršćanska forma engleskog "boljševizma”. Bez njenog uništenja ostaje novovjekovlje održano. Ali konačno uništenje može imati samo lik bitnog samouništenja, a koje će najsnažnije biti potaknuto putem prekoračenja vlastite prividne biti, a u ulozi spasitelja moralnosti. U kojem će historijskom momentu započeti samouništenje "komunizma", kao očito zbivanje i kraj, svejedno je, naspram iz obzora povijesti bitka, već donesene odluke, koja to čini neizbježnim. Prvi oblik samouništenja sastoji se u tome da se "komunizam" u provali ratničkih zbivanja izbacuje u ono nezadrživo svoga potpunoga prepuštanja moći” (Heidegger, 2014a: 157).

U Crnim bilježnicama nalaze se, dakle, s jedne strane šokantni antisemitski stavovi, te zatim ništa manje ekstremne prosudbe o istovjetnosti anglosaksonskog liberalizma i sovjetskog boljševizma. Dapače, po njemu je anglosaksonski svijet još bezobzirniji i brutalniji u potiranju povijesne kreativnosti od nasilne sovjetske politike. Stoga po Heideggeru Engleska i Amerika ne pripadaju zapadnjačkoj tradiciji, već su u opreci naspram Europe, zemlje bez povijesnih korijena i smisla. Nama pak izgleda da se takva vrsta pretencioznih nazovi-prosudbi može, kao prvo, objasniti jedino ideologijskim i nacionalističkim entuzijazmom toga razdoblja. Međutim, u navedenom se citatu isto tako jasno i ocrtava Heideggerovo osebujno poimanje zapadnjače povijesti, iz obzora povijesti bitka, i to kao prvog Grčkog i drugog Njemačkog početka. Tu izlazi na vidjelo prikrivena i izokrenuta hegelijanska koncepcija njegovog poimanja povijesti bitka. On to inače i sam izriče na posredan i ekscentrični način. Ovdje isto tako izlazi na vidjelo i njegovo potpuno samovoljno, neobrazloženo i neutemeljeno poimanje nastanka moderne države, razvoja i nastajanja političkih odnošenja, političkopravnog konstituiranja Europe od renesansa do suvremenosti, i to pod očitim utjecajem Nietzschea i Spenglera.

Slijedeći osobito karakteristični citati jasno pokazuju svu povijesno-političku i svjetonazorsku-kulturološku uvje- 
tovanost njegovog poimanja političkog: “"Politika” je po biću nešto novovjekovno, i kao takva uvijek politika moći, tj. uspostavljanje i izvršenje opunomoćenja moći, u od nje ovladanom onom opstojećem. Najviši način i akt politike sastoji se u tome da se protivnika izigra - dovede do stanja u kojem je prisiljen da korača ka svome vlastitom samouništenju. Pri tome politika mora imati dugu ruku i dugi dah i biti u stanju duže vrijeme primati udarce; i ne smije se dati smesti sa povremenim porazima opstojećeg" (Heidegger, 2014c: 260). Te zatim: “"Politika” je navlastiti izvršitelj tvorevine opstojećeg; nju se može samo metafizički pojmiti... I zato je govor o "politici moći” nesporazum... moć zahtijeva politiku da bi moć preko nje uspostavila ovladavanje tvorevinama. Ta je politika “totalna” - ne zato što ona sve obuhvaća, već zato što je po svome biću utemeljena u izvršenju opstojnosti opstojećeg" (ibid.: 43).

Novost i problematičnost stajališta u Crnim bilježnicama, naspram već poznatih teza iz prije objavljenih radova, sastoji se u izričitom konkretnom povijesno-političkom obzoru njegovih promišljanja. I, upravo u tome i jest problem, budući da su njegova poimanja onog političkog krajnje prijeporna i nedostatna, dapače, samoj naravi njegovog filozofiranja ono političko je nešto u biti strano, a o tome postoji više-manje konsenzus u znanstvenim istraživanjima njegovog filozofiranja. To isto tako izričito i višekratno tematizira i Hannah Arendt, jedna od njegovih prvih i najvjernijih učenica. To je i zasigurno i jedno od objašnjenja neodrživih i neobrazloženih političko-ideoloških tvrdnji iz navedenih citata. Tu se vidi kako Heidegger pokušava iz općih filozofijskopovijesnih promišljanja, odnosno, vlastite koncepcije o zaboravu bitka, onto- logijskoj diferenciji i epohalne prevlasti tehnike, obrazložiti teorijski okvir svoga ideološkog i teorijsko-politički apsurdnog stava o istovjetnosti engleske države i države Sovjetskih republika. Naime, po svemu sudeći tu se, prije svega, radi o prvenstveno političkim stajalištima, međutim pri tome je posebno problematičan i indikativan vokabular koji on rabi. Naime, Heidegger tu izričito govori o neophodnosti "konačnog uništenja" engleske "građansko-kršćanske države", a nakon toga, dakako, i slijedi uništenje komunizma-boljševizma. Takva se terminologija 30-ih godina ne može izdavati za filozofijsko promišljanje povijesti i zaborava bitka, bez obzira na kvazispekulativni dodatak da se pri tome u biti radi o nekakvom samouništenju. Dok se pak tvrdnja iz 1939. o ratničkom i ekspanzivnom komunizmu, opet u terminologiji povijesti bitka, mora držati za samo kamuflirani sastavni dio vladajuće nacionalsocijalističke ideologije. ${ }^{4}$

Kao što smo već naveli, Heidegger se u Crnim bilježnicama dosta bavi s problemom boljševizma, a koji izjednačava sa svjetskim židovstvom. Međutim, ni ta teza nije osobito originalna, jer se većina tih stavova već nalazi u Hitlerovoj knjizi Mein Kampf, kao i u mnogim političkim pamfletima toga vremena, naravno, izraženo u drugačijem propagandističko-vulgarnom govoru. Pri tome se svakako sa ne malim iznenađenjem treba istaknuti u kojem se visokom stupnju Heideggerovo razumijevanje nacionalsocijalizma, poklapa sa specifično Hitlerovim pogledima, to je vidljivo u njego-

4 Iz u međuvremenu ogromne literature o Heideggerovom odnosu spram politike i nacionalsocijalizma valja izdvojiti sljedeće novije radove a u kojima je i dana sva ostala relevantna literatura: Denker i Zaborowski, 2010a; 2010b; Fritsche, 1999; Faye, 2009; Zaborowski, 2010. 
vim opetovanim pohvalama specifično Hitlerovih postignuća, na primjer kada ističe, izgleda sasvim ozbiljno, Hitlerovu "genijalnu politiku" izbjegavanja rata na više fronta. Heidegger to još obrazlaže na sljedeći način: "Veliko iskustvo i sreća, kako je vođa probudio jednu novu zbiljnost, koja našem mišljenju daje pravu putanju i udarnu snagu. Inače bi se pokraj sve temeljitosti ostalo u samo-izgubljenosti i teško bi vodilo ka djelotvornosti. Literarna egzistencija je završena" (Heidegger, 2014b: 111). Ta se fascinacija Hitlerom posebno dobro vidi u nedavno objavljenoj korespondenciji sa bratom Fritzom. Tako on bratu Fritzu još za Božić 1931. toplo preporuča raspravu sa "Hitlerovom knjigom", jer tu se pokazuje kako Hitler ima "jedan neobičan i siguran politički instinkt”. Ta je preporuka za čitanje Mein Kampfa povezana sa izričitom obranom Hitlera, pa u pismu iz ožujka 1932. kaže kako je "narodni pokret buđenje nacije" i da je pri tome svejedno da li Hitler prema "nekoliko uplašenih "naobraženih" ima "nivo" ili ne" jer radi se o tome da "svaki pojedinac svoju odlučnu volju primjeni tamo, gdje se još nalazi jedini spas domovine". Dok u pismu od 12. siječnja 1945. kaže kako sada jedan svijet propada, ali koji "je ionako bio samo fasada, buka, zadovoljstvo i jednodušnost", ali "onaj jedini mišljenja povijesti bitka ide svojim putem i slijedi glas". Dok 12. veljače 1945. kaže kako taj jedini, tj. sam Heidegger, uviđa kako je "moje mišljenje bitak, a za njegovo se opravdanje ne nudi nigdje $u$ onome opstojećem neki temelj ili argument. Ovdje se otkriva samoća, koje se više ne tiče osobe, već budućeg nasljeđa čovječanstva”. Očito se sada u okrutnoj izvjesnosti propasti, od njega očekivanog "drugoga početka", razotkriva Heideggerovo očajanje $i$, istovremeno somnambulna, mitomanska vjera u po- slanstvo njegovog mišljenja povijesti bitka (Homolka i Heidegger, 2016).

Heideggerovo je razumijevanje boljševizma, s jedne strane sasvim tipično za to razdoblje, dok je s druge s obzirom na svoju radikalnost i patetičnost do danas zadržalo svoju specifičnu djelotvornost. Posebno putem prilično rasprostranjenih i u konzervativno-nacionalističkoj historiografiji i političkoj publicistici utjecajnih stajališta njegovog učenika historičara Ernsta Noltea. (usp. Nolte, 1998); u povezanosti s time vrlo je instruktivno i valja pogledati takozvani Historikestreit, u Njemačkoj 70-ih godina prošloga stoljeća (Piper, 1987), dodatno zanimljivo s obzirom na slične rasprave kod nas).

Heidegger navodi kako se on već dugo bavio boljševizmom, te kaže: "Moje osvješćenje onog ruskog počinje godine 1908-9 u pokušaju... poimanja onog ruskog. Od tada je ta volja išla svojim putem i nije bila određena nadolaskom boljševizma, niti putem političkog "razvitka" odnošenja između Rusije i Njemačke od siječnja 1939. Političko-taktički, tj. historijsko-tehnički odnos između Rusije i Njemačke, tj. "stranaka" koje vode te države imat će "historijske" ovakve ili onakve posljedice - ali taj odnos nije nikada mogući temelj i prostor, iz obzora povijesti bitka, za raspravu između onog njemačkog i ruskog. Ta rasprava može proizaći samo iz prevladavanju historije preko vladavine povijesti bitka" (Heidegger, 2014c: 148). No, pogledajmo kako Heidegger, nakon 30 godina bavljenja pitanjem Rusije, vidi aktualne ruske odnose. Rusija je sada postala komunističko-boljševistička, a to po Heideggeru znači da je preko židovskog duha otuđena od vlastite biti. Ono istinito rusko, naglašava češće Heidegger, upravo je po svome biću strano komunizmu i marksizmu. I to je doista intui- 
tivno lako shvatljivo, budući da utemeljitelji i glavni predstavnici toga učenja nisu bili nikakvi Rusi. Nasuprot tome, valja navesti da je jedna od prvih i vrlo utjecajnih, te do danas aktualna kritika Marxovog učenja inicirana od Rusa Bakunjina i njegovih sljedbenika, a bila je itekako poznata u Njemačkoj i Francuskoj upravo u vrijeme ovih Heideggerovih bilježaka, posebno u mišljenju ruskog filozofa Berdjajeva, a koji je osim toga i polemizirao s Heideggerom.

Inače, Heidegger češće patetično naglašava, kao značajni uvid i novu veliku istinu, sljedeću tezu: "Boljševizam nema ništa zajedničkog $s$ azijatskim i još manje sa slavenstvom i onim ruskim - dakle, sa arijskim temeljnim bićem - on proizlazi iz zapadnjačko-zapadne novovjekovne racionalne metafizike" (ibid.: 47) Taj je stav Heideggera samo varijacija njegovog općeg stava, iz obzora povijesti bitka, o neophodnosti destrukcije zapadnjačke ontoteologije, tj. platonizma. U tako shvaćenom platonizmu uspostavljeno je transcendentno vječno carstvo ideja, odnosno, na taj je način konstituirano jedno novo sudbonosno poimanje bitka, a na način zaborava bitka. Time je, po Heideggeru, uspostavljena dugovječna i sudbonosna vladavina platonizma u duhovnoj povijesti zapadnjačkog svijeta, i to prvo posredovanjem kršćanstva, zatim univerzaliziranjem židovskog transcendentnog boga, pa sekulariziranjem kršćanstva u doba prosvjetiteljstva, te konačno putem liberalizma i socijalizma. To Heidegger na jednom drugom mjestu ovako izražava: "Iz toga se [platonskog] učenja o idejama određuje cjelina duhovnog bitka zapada do danas. Pojam Boga također proizlazi iz ideje, i prirodne se znanosti na njoj orijentiraju. Kršćanska i racionalistička misao spajaju se ujedno od Hegela. A Hegel je ponovno temelj mar- ksizma. Kada ne bi bilo učenja o idejama, ne bi bilo ni marksizma. Marksizam stoga može biti konačno savladan, tek kada se mi prethodno razračunamo $s$ učenjem o idejama i njihovom dvijetisućljetnom poviješću" (Heidegger, 2001: 151). Taj se stav zatim još precizira, te ga se može shvatiti kao jednu od temeljnih teza njegove političke filozofije, a glasi ovako: "Pri tome je [u platonizmu] čovjek shvaćen kao opće umno biće. U prosvjetiteljstvu i liberalizmu dospio je taj pojam do jedne određene forme. Tu je korijen svih današnjih snaga sa kojima se valja boriti. Tome je shvaćanju suprotstavljena konačnost, vremenitost i povijesnost čovjeka" (ibid.: 166).

Kao što smo naveli Heidegger zaključuje kako će se nakon 1939. odnos između Njemačke i Rusije i vodećih "stranaka" koje ih vode "historijski" već nekako razriješiti, te, dapače, tvrdi da postoje bitne sličnosti između Nijemaca i Rusa. Međutim te tvrdnje, kao vrlo često u Crnim bilježnicama nisu dalje obrazložene, te sve ostaje u sljedećim mitsko-kriptičkim metaforama: "Nerazotkrivena tajna onog ruskog (ne boljševizma) može biti kao takva dana i utemeljena samo putem nekog odgovarajućeg izvornog - a koje ostavlja iza sebe svu metafiziku i sav kršćanski kulturni pogon - misaonog kazivanja provalije bitka" (Heidegger, 2014c: 48). Heidegger zatim pokušava tu tajnu onog ruskog razjasniti u povezanosti sa Njemačkom na sljedeći način:

"Zašto ne bi čišćenje i osiguranje rase bilo određeno time da jednom ima za posljedicu veliko miješanje: sa Slavenstvom (sa onim ruskim - kojem je boljševizam samo nametnut i nije mu u korijenju)? Ne bi li morao tamo njemački duh, u svojoj najvišoj suzdržljivosti i strogoći, savladati tminu i istovremeno je priznati kao svoj temeljni korijen? $\mathrm{Ne}$ 
bi li tako moglo nastati jedno čovječanstvo, koje bi bilo doraslo utemeljenju istine bitka i pozvano ka božanskim sposobnostima. Što, ako bi politička svršenost novovjekovlja morala prirediti to ujedinjenje, prvotno putem puno zaobilaznica, i u naizgled krajnjim oprekama?... i pri tome bi u tome povijesnobitnom ujedinjenju "ono "racionalno" i "iracionalno" bili samo prividno, naizgled nešto različito” (ibid.: 402, 403).

Ove su rečenice pisane vjerojatno pred kraj 1939., dakle, nakon iznenađujućih pregovora Njemačke i Sovjetskog Saveza, a u njima Heidegger, svakako krajnje iznenađujuće, nagovještava mogućnost razrješenja nacističke rasne politike putem osebujnog sjedinjenja sa onim ruskim, a to bi onda i mogao biti put ka, po njemu koncipiranom mogućem novom, drugom početku zapadnjačke povijesti. Ali da bi tako nešto uopće bilo ostvarivo "trebali bi tada Nijemci biti oboružani sa najdubljim prisvajanjem zapadnjačke povijesti bitka i znanja, za polemos koji si je izborio područje odlučivanja u okviru kojeg bi neproračunljivo biće bogova i onog ljudskoga našlo svoju dubinu” (ibid.: 402). Heidegger ovdje očigledno predmnijeva, a putem njegovog osebujnog poimanja polemosa, susret u okviru povijesti bitka, između Nijemaca i Rusa, a u cilju prevladavanja zaborava bitka, odnosno, metafizičkog tehničko-tehnologijskog svijeta moderne. Stoga on vidi "tu budućnost zapada" ostvarivu putem "ujedinjenja onog njemačkog i ruskog" a koje "dospijeva do naj-krajnjeg uzdizanja svršenosti novovjekovlja”. Tu se po Heideggeru radi o dva u povijesti bitka oprečna načela, to su "neiscrpnost ruske zemlje i neodoljivost njemačkog planiranja i uredovanja”. Ta se dva načela moraju "držati u njihovoj nenadvisivosti u neodlučnosti, a ta- kva će neodlučnost biti svršenost ogromnosti (Riesenhaft) u tvorevinama (Machenschaft)" (ibid.: 403).

Heidegger ovdje očito zagovara ujedinjenje ta dva različita načela bitka, još karakterizirana kao ono "racionalno" i "iracionalno", a sa svrhom prevladavanja metafizičkog doba, mada i istovremeno upozorava na "najveću opasnost" ostanka u liku dosegnutog vrhunca metafizičke moderne. Zatim Heidegger opetovano pokušava zahvatiti metafizičku bit sovjetskog socijalizma na slijedeći način: "Prvi i odlučujuću korak ka bezuvjetnom motoriziranju ljudskog izvršio je sovjetski socijalizam; drugi su ga slijedili samo u protuobrani u onome bitnom. Taj je socijalizam samog sebe kao prvo spoznao kao onaj sistem bezuvjetnog ovlaštenja moći u kojem je tehnici određeno njeno konačno metafizičko mjesto. Sovjetska je moć prema Lenjinu "socijalizam + elektrifikacija”. U području tih bitnih koraka svršenosti metafizike kao tvorevine, nije bitno tko sprovodi taj sistem bezuvjetne moći, već tko ga je bitno spoznao i poduhvatio u njegovoj biti... tu postaje očita metafizička bijeda Talijana, naspram onog ruskog. Jedino bezuvjetna ljudskost koja se ne predaje pred krajnjom subjektivnošću, dovoljno je jaka da se podvrgne bezuvjetnoj metafizičkoj biti tehnike. Ali ni ono rusko ne dospijeva do te bezuvjetnosti" (ibid.: 257). Neovisno o svoj prijepornosti ovih tvrdnji iz mišljenja povijesti bitka, ipak je začuđujuće, pa makar to bilo i na vulgarno faktičnoj razini, kako Heidegger nije zamijetio da je proskribirano "bezuvjetno motoriziranje ljudskog” kao prvo sprovedeno u zapadnoj Europi, zatim historijski jako ubrzano u 19. stoljeću u Njemačkoj, pa tek onda sa znatnim zakašnjenjem, no isto tako historijski jako ubrzano, u Sovjetskom Savezu. 
$\mathrm{Na}$ ta se određenja metafizike sovjetskog socijalizma neposredno nadovezuju promišljanja o amerikanizmu na sljedeći način: "Amerikanizam je historijski ustanovljiva pojava bezuvjetnog okončanja novovjekovlja u opustošenju. Ono rusko ima u jednoznačnosti brutalnosti i upornosti istovremeno korjenito izvorno područje u svojoj zemlji koja je predodređena ka svjetskoj jednoznačnosti. Oprečno amerikanizam je sakupljanje svega, to sakupljanje znači uvijek istovremeno iskorjenjene skupljenog. Čim se to uzdigne do bezuvjetne postojanosti čisto povijesno ostvarivog, ima se zacijelo sve, ali je istovremeno svakom oduzeta njegova izvornost. U tu metafizičku zonu opustošenja ono rusko se ne spušta; jer ono ima, neovisno od "socijalizma” u sebi jednu mogućnost početka, a koja je svakom amerikanizmu unaprijed nedostupna. Ono je rusko svemu usprkos ukorijenjeno u tlu i protivno umu, a da bi bilo u stanju preuzeti povijesno određenje opustošenja. Da bi se prihvatio zaborav bitka, i kao takav uspostavio i da bi se kao habitus održao, za to je potrebna jedna u najvišem stupnju gotova i sve proračunavajuća umnost, koju se, ako se hoće, može još nazvati "duhovnost". Samo takav "duh" ostaje dorastao povijesnoj zadaći opustošenja. Ulogu pomagača preuzeo je u okviru toga opustošenja "narod gospodara" Englezi. Metafizička ništavnost njihove povijesti sada izlazi na svjetlo dana. Oni samo traže spas te ništavnosti, i time daju svoj doprinos opustošenju" (ibid.: 258). Međutim, ovdje ipak valja reći da je veliki dio tih stajališta originalan samo po svojoj osebujnoj terminologiji i apodiktičkom impetusu, ali sadržajno gledano to je jedna od varijacija na teme, teze i raspoloženja mislilaca iz kruga takozvane "konzervativne revolucije" u Njemačkoj s početka 20. stoljeća. Tu se posebno mogu spomenuti autori kao Spengler, Junger i Schmitt. Stoga nam izgleda da se u ovakvim Heideggerovim "osvještenjima” doista prvenstveno radi, usprkos njegovom izričitom negiranju, o aforizmima i životnim mudrostima u stilu Nietzschea ili pak možda o "uputama ka blaženom životu" a la Fichte.

Kada se govori o Heideggerovom shvaćanju problema Rusije i njemačkoruskih odnosa, svakako valja navesti da su 1913. na njemački prevedeni Politički spisi od Dostojevskog. U tim se tekstovima nalazi mnoštvo dubokoumnih i iznijansiranih promišljanja i opažanja Dostojevskog o Njemačkoj i Nijemcima, o Rusiji i Rusima, te o odnosima Rusije, Njemačke i Europe. Ti tekstovi Dostojevskog, kao i njegova literarna djela, bila su 20-ih godina intenzivno diskutirana, proučavana i recipirana u Njemačkoj kao i cijeloj Europi. Posebno su bile plodne i utjecajne rasprave Thomasa Manna u njegovim znamenitim kulturno-političkim esejima o ulozi i značenju Njemačke u Europi, kao i naspram Rusije, u viđenju Dostojevskog, i sa time povezana njegova određenja uloge onog političkog u povijesnom razvoju njemačkog duha. ${ }^{5} \mathrm{U}$ Heideggerovim Crnim bilježnicama nažalost nema nikakve upute na te tekstove Dostojevskog, mada ih je on jamačno poznavao, na koncu u njegovoj je radnoj sobi u Freiburgu visjela slika Dostojevskog. Stoga je vrlo uputno i preporučljivo pogledati kako Dostojevski vidi bit Njemačke i njen odnos spram zapada i Rusije, posebno radi potpunijeg poimanja Heideggerovih stajališta.

U eseju "Njemačko svjetsko pitanje" kaže Dostojevski sljedeće: "Već je prije postojala ta zadaća Njemačke, njena jedina, od kada uopće ima Njemačke. To

\footnotetext{
5 Vidi: Gretić, 2015.
} 
je njeno protestantstvo: ne samo ona formula protestantizma, koja se razvila u vrijeme Luthera, već njen vječni protestantizam, koji je jednom započeo s Arnimom protiv rimskog svijeta, protiv svega što je bio Rim i rimska zadaća, i kasnije protiv svega što je od starog Rima prešlo na novi Rim, i na sve narode koji su prihvatili rimsku ideju, njegovu formulu i bit, protest protiv nasljeđa Rima i protiv svega što je činilo to nasljeđe... Ja uzimam samo temeljnu ideju koja je rođena još prije dvije tisuće godina i od toga vremena nije umrla, iako se neprestano utjelovljivala $u$ različitim formulama... Stari Rim bio je prva sila koja je proizvela ideju jednog univerzalnog ujedinjenja ljudi, i prva koja je vjerovala i bila čvrsto uvjerena da je može praktički ozbiljiti u liku svjetske monarhije. Međutim ta je formula pronađena prije kršćanstva - formula, ali ne i ideja. Jer to je ideja o ideji europskog ljudstva, iz nje se stvara njena kultura i samo za nju ona živi. Jedino je nedostajala puka ideja univerzalne rimske monarhije, a ona je bila zamijenjena putem novog ideala jednog ponovnog univerzalnog novog sjedinjenja u Kristu. Taj se novi ideal rascijepio u ono javno, i u ideal savršenog duhovnog sjedinjenja ljudi $u$ idealu zapadno-europskom, rimsko-katoličkom pape, a koji je bio sasvim suprotstavljen onom javnom. To se svjetsko, rimsko-katoličko utjelovljenje ideje odvijalo na svoj način, bez da je u potpunosti izgubilo kršćanski, duhovni izvor te ideje, i to na način da je tu ideju spojilo sa starorimskim nasljeđem. Rimski je papa obznanio da kršćanstvo i njegova ideja ne mogu biti ozbiljeni bez univerzalnog ovladavanja zemalja i naroda, ne duhovno nego državno, drugim riječima ne bez zemaljskog ozbiljenja jedne nove univerzalne rimske monarhije, a čiji poglavar ne bi bio rimski imperator, već papa". Zatim nastavlja Dostojevski: "Ali što sve to u svih tih dvije tisuće godina ima zajedno sa Njemačkom? Ona karakteristična, bitna crta toga velikoga, ponosnog i posebnog naroda sastoji se već od prvog trenutka njegovog nastupa u povijesnom svijetu u tome da se nikada nije htio sjediniti niti u svojem određenju ni u svojim načelima sa ranijim zapadnim europskim svijetom, tj. sa svim nasljeđem starorimskih određenja. Ona je protestirala protiv toga svijeta svih dvije tisuće godina, i iako još nije izrekla svoju riječ - i još je uopće nikada nije izrekla, svoj oštro formulirani vlastiti ideal, kao pozitivni nadomjestak za od nje razorenu starorimsku ideju... u srcu je bila uvjerena da će jednom biti u stanju reći tu novi riječ i sa njime voditi čovječanstvo...u vrijeme rimskog kršćanstva borila se s novim Rimom za prevlast više od svih drugih naroda. I konačno je protestirala na najmoćniji način, putem nalaženja nove formule protesta iz najduhovnijih, najelementarnijih temelja germanskoga svijeta. Iz njega se čuo božji glas obznanjujući slobodu duha... U isto vrijeme [nakon Francuske revolucije i Napoleonovih ratova] pojmio je njemački duh da je, naime, njemačka zadaća kao prvo bila samo jedna, prije svih ostalih stvari i novih početaka, prije svakog pokušaja jedne nove riječi, protiv iz stare katoličke ideje preoblikovanog protivnika - uspostaviti vlastito političko jedinstvo, dovršiti stvaranje vlastitog državnog organizma, i tek nakon što se je to dogodilo, suprotstaviti se sučelice svome starom protivniku. I tako se dogodilo" (Dostojewski, 1920: 65-67, 69-70, 72). I nakon Francuskopruskog rata 1871. Dostojevski ovako određuje položaj Njemačke: "Njemačka je u Europi ipak zemlja koja leži u sredini: i koliko god bila jaka - s jedne strane ostaje Francuska, a sa druge Rusija. Isti- 
na je Rusi su za sada još ljubazni. Ali što ako oni iznenada otkriju da nisu oni ti koji trebaju savez sa Njemačkom, već Njemačka savez sa Rusijom; i iznad svega još da je ovisnost toga saveza sa Rusijom, kako po svemu izgleda sudbonosno određenje Njemačke, i to posebno nakon Njemačko-Francuskog rata" (ibid.: 77).

Sada valja vrlo sažeto iznijeti temeljne teze Dostojevskog o Rusiji i njenoj povijesnoj zadaći u Europi i svijetu; kao prvo Rusija se "izgradila do jedinstva i namjerava osigurati svoje granice, a $u$ sebi je znala da u sebi nosi jedno blago i da na svijetu nema ništa tome sličnog pravoslavlje; znala je da čuvarica istine Krista... i u Moskvi se došlo čak do uvjerenja da bi svako bliže dodirivanje sa Europom moglo djelovati loše i demoralizirajuće na rusku ćud i na Rusku ideju, na samo pravoslavlje" (ibid.: 191). Zatim pobliže određuje rusku ideju: "jednom riječju, to je moguće upravo početak, prvi korak aktivnog primjenjivanja našeg blaga, našeg pravoslavlja ka službi za cjelokupno čovječanstvo - što je njeno određenje i što čini njeno pravo biće... mi smo spoznali naše svjetsko određenje, našu osobnost i našu ulogu u čovječanstvu, ali smo predvidjeli da su to značenje i ta uloga temeljno različiti od one drugih naroda, jer tamo živi svaka nacionalna osobnost jedino za sebe i u sebi, ali mi ćemo kada dođe naše vrijeme, upravo početi time da budemo $u$ službi svih, a za volju općeg pomirenja... to je naša veličina, jer vodi ka konačno pomirenju čovječanstva... Tako ja razumijem rusku predestinaciju i njen ideal" (ibid.: 193). Te zatim: "što je to, to "pravoslavlje”? i gdje tu leži neka posebna ideja, takvo posebno pravo na ujedinjenje naroda? Nije li to isto tako politički savez kao svi drugi, iako na širim temeljima, možda na način Sjedinjenih Ame- ričkih Država? Ali ne baš isto, jer tu se radi o savezu koji je "utemeljen na sveuslužnosti za čovječanstvo”... na vjeri u bratstvo ljudi, na sve-pomirenju naroda" (ibid.: 199). Međutim, Dostojevski tu ističe nešto po njemu čudno i posebno, naime: "Zašto se skoro devet desetina Rusa, koji su se u ovom stoljeću obrazovali u Europi, uvijek priključila onim strankama u Europi koje su bile liberalne, "lijeve", tj. uvijek onoj strani koja je negirala vlastitu civilizaciju, svoju vlastitu kulturu?" (ibid.: 179). Odnosno, ne znači li to priklanjanje ruskih zapadnjaka "krajnjoj ljevici" zapravo priklanjanje "negirajućim elementima Europe, upravo negatorima Europe - ne pokazuje li se tu protestirajuća ruska duša kojoj je europska kultura... oduvijek bila omražena, koja se u mnogome, u previše toga dokazala kao nešto strano ruskoj duši” (ibid.: 181). Te na koncu Dostojevski zaključuje da "Rus koji postaje pravi europejac ne može drugo, nego da istovremeno postane prirodni neprijatelj $\mathrm{Ru}-$ sije" (ibid.: 189). Tako na koncu, po Dostojevskom, postoje dva tipa civiliziranih Rusa, onaj koji upoznajući Europu postaje najveći Rus, i onaj koji postajući Europejac prelazi na katoličanstvo i, dapače, priključuje se Jezuitima. Stoga se Dostojevski istovremeno pita nije li to zapravo ono što Europa hoće po pitanju Rusije, te dodaje, kako Europa ima pravo kada prekorijeva Ruse radi njihove revolucionarnosti, jer "mi smo revolucionari iz neke vlastite nužnosti, tako reći revolucionari iz konzervativizma" (ibid.: 190). I, konačno, ta ideja Rusije, "pravoslavlja" u smislu posebnog prava ujedinjenja i pomirenja naroda, daje Rusiji pravo i zadaću prisvajanja Konstantinopolisa, te "prve političke točke svijeta" i sjedišta "najstarije i najmoćnije kulture" (ibid.: 195). Stoga to svjetskopovijesno određenje Bizanta može ozbiljiti i ispu- 
niti jedino Rusija, kao zaštitnica i čuvarica starog Bizanta, a na dobrobit Slavena i Grka.

Nama izgleda da nije teško vidjeti da postoje očite srodnosti, sličnosti između Heideggerovih promišljanja iz povijesti bitka o odnosu Nijemaca i Rusa, sa teologijsko-filozofijskim spekulacijama Dostojevskog. To sada nije moguće dalje razrađivati u okviru ovoga rada, mada svakako valja ustanoviti jednu sasvim izuzetnu različitost u sličnosti. Heidegger govori o mogućem svjetsko-povijesnom ujedinjenju onog njemačkog i onog ruskoga kao mogućnosti započinjanja drugog početka svjetske povijesti, dok Dostojevski isto tako promišlja mogućnosti novih povijesnih konstelacijama i i na koncu ih vidi u novom ozbiljenju ideje pravoslavlja putem suradnje Slavena i Grka.

I konačno, vrlo je instruktivno pogledati na koji način i kako Heidegger u svojim promišljanjima povijesti bitka koncem 30-ih godina, objašnjava slom zapada, trijumf komunizma i zatim drugi povijesni početak, nadolaskom nacionalsocijalističkog pokreta, sa pojmovljem iz djela Bitak i vrijeme. Heidegger to ovako izražava:

"Tako nesposobnost znanja o biti "brige" proizlazi iz upornog ostajanja pri metafizici, a koja je postala nešto po sebi obično, i to u njenom posljednjem trijumfu: u "komunizmu" kao ljudskog podupiratelja tvorevina. Njena je "vladavina" kraj prvog početka bitka. Iznenadni polazak ka tome kraju drugi je početak te povijesti. U prvom početku biva bitak kao niknuće (phisis); u drugom početku biva bitak kao događaj. Rastenje, tvorevina, događaj su povijest bitka, ukoliko oni oslobađaju bit povijesti iz prvotne prikrivenosti, preko izokretanja u historiju, spram onog što će oni budući misliti unaprijed i na istinu bitka, kao utemeljenje svjetline izvršenja" (Heidegger, 2014c: 157).

A u horizontu promišljanja povijesti bitka, Heidegger na sljedeći način govori o svjetsko-povijesnoj ulozi Engleske i židovstva, a nastavljajući se na prethodna promišljanja: "Zašto mi spoznajemo tako kasno da Engleska uistinu jest i može biti bez zapadnjačkog habitusa? Jer ćemo mi tek u budućnosti pojmiti da je Engleska započela uspostavljati novovjekovni svijet, ali novovjekovlje je po svome biću usmjereno ka oslobađanju tvorevina na cjelokupnoj zemaljskoj kugli. Isto tako i pomisao o sporazumijevanju sa Engleskom u smislu "pravedne" imperijalističke podjele, ne pogađa bit povijesnih događanja, a koje sada Engleska igra do kraja u okviru amerikanizma $i$ boljševizma, tj. istovremeno također $i$ svjetskog židovstva. Pitanje o ulozi svjetskog židovstva nije nikakvo rasno, već metafizičko pitanje" (ibid.: 243). Sa tvrdnjom da je Engleska bez zapadnjačkog habitusa zapravo se vrlo teško može smisleno polemizirati, budući da zapadnjački i novovjekovni habitus zasigurno nisu ono što Heidegger poima pod prvim Grčkim početkom, a još manje ono što bi trebao biti drugi, Njemački početak. U završnim razmatranjima izgleda kako Heidegger doista misli kako su sve novovjekovne revolucije proizišle iz židovskih svjetskopovijesnih mešetarenja. Pri tome je "zapad" zapravo bio bitno i odlučno napadnut tim revolucijama, ali to nije shvaćao i čak lakoumno mislio da se bori protiv njih. Stoga na kraju, u nekoj vrsti rezigniranog rezimea, Heidegger tvrdi kako je konačno potpuno svejedno tko će pobijediti ili propasti u toj borbi za svjetsku prevlast, budući da se ionako sve odvija na razini metafizike, a to znači daleko od nekoga zbiljskog novog početka. 


\section{REFERENCE}

Denker, A. i Zaborowski, H. (2010b) Heidegger-Jahrbuch 5: Heidegger und der Nationalsozialismus II. Freiburg: Verlag Karl Alber.

Denker, A. i Zaborowski, H. (2010a) Heidegger-Jahrbuch 4: Heidegger und der Nationalsozialismus I. Freiburg: Verlag Karl Alber.

Di Cesare, D. (2015) Heidegger, die Juden, die Shoah. Frankfurt: Klostermann.

Dostojewski, F. M. (1920) Politische Schriften. München: Piper Verlag,

Faye, E. (2009) Heidegger. Die Einfuhrung des Nationalsozialismus in die Philosophie. Berlin: Matthes \& Seitz.

Fritsche, J. (1999) Historical Destiny and National Socialism in Heidegger's Being and Time. Los Angeles: University of California Press.

Gander, H. H. i Striet, M. (2016) Heideggers Weg in die Moderne. Frankfurt: Klostermann.

Gretić, G. (2015) Revolucionarna umjetnost - nacionalizam - antisemitizam: slučaj Wagner. Anali HPD-a 11(1): 73 93.

Gretić, G. (2012) Problem drugog istranog. Zagreb: Breza.

Heidegger, M. (2014b) Gesamtausgabe. Überlegungen II - VI. Frankfurt: Klostermann.

Heidegger, M. (2014a) Gesamtausgabe. Anmerkungen, I-IV. Frankfurt: Klostermann.
Heidegger, M. (2014c) Gesamtausgabe. Überlegungen XII - XV. Frankfurt: Klostermann.

Heidegger, M. (2014d) Gesamtausgabe. Überlegungen VII - XI. Frankfurt: Klostermann.

Heidegger, M. (2001) Sein und Wahrheit. Frankfurt: Suhrkamp Verlag.

Heinz, M. i Kellerer, S. (2016) Martin Heideggers "Schwartze Heften": Eine philosophish-politish Debatte. Frankfurt: Suhrkamp Verlag.

Homolka, W. i Heidegger, A. (2016) Heidegger und Antisemitismus: Positionen im Wiederstreit. Freiburg: Herder Verlag.

Löwith K. (1986) Mein Leben in Deutschland vor und nach 1933. Stuttgart: J. B. Metzler.

Nolte, E. (1998) Martin Heidegger. Politik und Geschichte im Leben und Denken. Berlin: Propyläen Verlag.

Piper, E. H. (ur.) (1987) Historikerstreit. München: Piper Verlag

Trawny, P. (2016) Heidegger und der Mythos der jüdische Weltverschworung. Frankfurt: Klostermann.

Zaborowski, H. (2010) Eine Frage von Irre und Schuld?: Martin Heidegger und der Nationalsozialismus. Frankfurt: Fischer. 


\section{Heidegger's criticism of bolshevism and liberalism}

ABSTRACT The article discusses Heidegger's advocacy of the idea of national-socialism and through contextual reading of Black Notebooks, his criticism of communism and Anglo-American liberalism. Taking into account the intellectual and the political context in which Black Notebooks were written, the author offers insight into Heidegger's peculiar antisemitism and its link to his wider philosophical project on the history of the Being. This approach, the author shows, is in the core of Heidegger's criticism of Soviet communism. Last part of the paper is devoted to the comparison of Dostoyevsky's view on the role of Russian people with Heidegger's view on that topic.

KEY WORDS Heidegger, Black Notebooks, National Socialism, communism, bolshevism, liberalism 